\title{
Physico-Chemical Analysis of Milk Prepared from Broken Rice
}

\author{
M. Padma ${ }^{1 *}$, P.V.K. Jagannadarao ${ }^{2}$, L. Edukondalu ${ }^{1}$, G. Ravibabu ${ }^{1}$ and K. Aparna ${ }^{1}$ \\ ${ }^{1}$ College of Agriculture Engineering, Kandi, Sangareddy-502319, India \\ ${ }^{2}$ Ag. Engg., Regional Agricultural Research Station, Anakapalle, India \\ *Corresponding author
}

\section{A B S T R A C T}

\begin{tabular}{|l|}
\hline K e y w o r d s \\
$\begin{array}{l}\text { Rice brokens, Rice } \\
\text { milk, Non-dairy milk } \\
\text { products, Soaking, } \\
\text { Cooking, Blending }\end{array}$ \\
\hline Article Info \\
\hline $\begin{array}{l}\text { Accepted: } \\
\text { 08 January } 2018 \\
\text { Available Online: } \\
\text { 10 February } 2018\end{array}$ \\
\hline
\end{tabular}

Rice (Oryza sativa L.) is the second most important cereal grain consumed worldwide and providing carbohydrates, proteins, fats, fibers, minerals, vitamins, etc. Rice is also considered as one of the major sources of nutrients. It has high digestibility, biological value and protein efficiency ratio owing to the presence of high concentration of lysine among all the cereals. Rice milk was prepared by cooking the soaked broken rice for the duration of $1,2,3 \mathrm{~h}$ and blending the cooked broken rice with water at 1:1,1:2 and 1:3 ratios and physico chemical properties were analysed for the milk prepared at different soaking, cooking and blending ratios. The results were observed for all the samples and analyzed with design Experts software and the optimized sample among three blending ratios. The sample prepared at $1: 3$ blending ratios is the best because the $\mathrm{p}^{\mathrm{H}}$ of the sample varies between 5.98 to 6.05 which is less acidic, Total soluble solids were less which was in the range of 4 to 5 brix. Titrable acidity values were less when compared with other two ratios which were in the range of 0.02 to $0.03 \%$. According to the sensory evaluation the sample $\mathrm{s} 1$ is the best.

\section{Introduction}

Rice is one of the most important staple foods for nearly half of the population in the world. Worldwide production area of rice is about 160.6 million ha, while the annual production is about 490 million tonnes (FAO, 2016). Asian region contributes approximately $90 \%$ of the total global rice production out of which China and India contribute $28.7 \%$ and $19.5 \%$ share of total production, respectively. Major rice producing states in India are West Bengal, Uttar Pradesh, Andhra Pradesh, Punjab, Bihar, Orissa, Chhattisgarh, Assam, Tamil Nadu and Haryana. India is now self-sufficient in rice production and is also one of the leading exporters of rice in the world market. Rice (Oryza sativa L.) is the second most important cereal grain consumed worldwide and providing carbohydrates, proteins, fats, fibers, minerals, vitamins, etc. (Juliano,1993). Rice is also considered as one of the major sources of nutrients. It has high digestibility, biological value and protein efficiency ratio owing to the presence of high concentration of lysine among all the cereals.

Rice husk, rice bran and broken rice are the main by-products of the rice industry. Besides having nutritional and medicinal benefits, the by-products of rice, namely, rice bran and broken rice are equally important and 
beneficial. Undesirable parts, that are discarded through the milling process, and the edible part of rice mainly broken rice could be transformed into various value added products like rice flour, rice milk, rice puddings, rice starch, rice glue, rice cakes, etc. Demand for rice is expected to remain strong over the next few decades due to the economic and population growth forecast in many countries, including African and Asian countries. Therefore, the rice industry will remain sustainable for a long time, and the availability of rice by-products is ensured (Esa et al., 2013).

Milk and other dairy products are major source of calcium and it is essential for the growth and repair of the bones. Shortage of calcium may lead to thin, fragile bones those break easily in both children and adults. Lactose intolerance in human beings is the inability to digest significant amounts of lactose, the predominant sugar of milk. This inability results from shortage of the enzyme, lactase, which is normally produced by the human cells that can then be absorbed into the bloodstream. A common symptom of lactose intolerance includes nausea, cramps, bloating, gas, diarrhea, etc. Therefore, rice milk which is free from lactose maintains the nutritive value similar to dairy milk may be accepted by the consumers (Churdchai et al., 2001). In earlier studies, the rice milk prepared from whole rice, but it is economical to prepare milk from broken rice because of value addition to this by-product of rice industry. As the cost of broken rice is less (generally half the price of whole rice), cost of rice milk prepared from brokens is less when compared with the whole rice milk.

\section{Materials and Methods}

This chapter describes the detailed description of methodology of rice milk preparation. This methodology was conducted in Food
Processing Lab at College of Agricultural Engineering, Sangareddy. The method consists of preparation of rice milk from broken rice at room temperature and hygienic conditions.

\section{Raw materials}

Variety of broken rice taken-Sonamasuri

\section{Chemicals}

$\alpha$ - amaylase

Xanthangum

Sodium Hydroxide, Anhydrous pellets

Buffer solution

\section{Equipments}

\section{Mixer}

Induction stove

$\mathrm{pH}$ meter

Spectrophoto meter

Refractrometer

\section{Procedure for preparation of rice milk}

Broken rice of $1 \mathrm{~kg}$ were procured from a local market and cleaned for several times to remove dust, dirt and to reduce the chance of contamination. The cleaned broken rice were soaked with 1:2 parts of water for $1 \mathrm{hr}$. Presoaking reduced the cooking time required to soften the centre of the rice kernel Apparent amylose content decreased after soaking. After the soaking period of $1 \mathrm{hr}$ the water is drained out from the brokens using filter net. As the water consists of harmful toxins which are released during soaking, were drained off. The drained broken rice were taken and made into three equal parts. One part of drained broken rice was cooked with 1:1 parts of water. The second part of drained broken rice was cooked with 1:2 parts of water. And the third part of drained broken rice was cooked with 1:3 parts of water. The cooking temperature is 
maintained $80^{\circ} \mathrm{C}$ and cooked for $15 \mathrm{mins}$ which is the optimum condition for cooking. Broken rice with high amylose content had the shortest minimum cooking time. While cooking $0.22 \%$ of $\alpha$-amalyze is added for faster rate of cooking. Now the gelatinized starch obtained from 1:1 cooking was divided into three parts from which one part was blended with 1:1 parts of water for homogenization. The second part with 1:2 water and third part with 1:3 water were blended. The obtained broken rice milk is filtered by a filter paper. Finally the rice milk is prepared. Add $0.33 \%$ of xanthangum to the rice milk to prevent settling of particles.

Physico-chemical analysis of rice milk prepared from broken rice

\section{Measurement of pH}

$\mathrm{pH}$ of the sample were measured using a digital $\mathrm{pH}$ meter in triplicates. The probe of $\mathrm{pH}$ meter was inserted into sample and the stable reading obtained was considered as the final $\mathrm{pH}$ value.

\section{Measurement of Total Soluble Solids (TSS)}

Total soluble solids (TSS) indicate the thickness of sample. Total soluble solids (TSS) of sample was determined using a digital handheld refractometer (Model: PAL1; Make: Atago, Japan), having a range of 0$53 \%$ according to the methods proposed by Ranganna (1991). Before measurement of TSS of sample, the refractometer was calibrated using double distilled water. A drop of the rice milk was placed on the sample slot of refractometer and the TSS of the sample was recorded and expressed in ${ }^{\circ}$ Brix.

\section{Measurement of titratable acidity (TA)}

Titratable acidity (TA) in the sample was determined by titration method proposed by
Ranganna (1991). Briefly, $10 \mathrm{~mL}$ of rice milk sample was taken and diluted to $30 \mathrm{~mL}$ with distilled water. $10 \mathrm{~mL}$ diluted sample was taken for titration, mix 2-4 drops of $1 \%$ phenolphthalein indicator and titrated against 0 .

\section{Measurement of color}

Color of rice milk was measured based on the International Commission on Illumination color parameters L* (0-100, Black-Lightness), $a^{*}$ (positive values - red, negative valuesgreen and 0 is neutral) and $b^{*}$ (positive values - yellow, negative values- blue and 0 is neutral). Colorimeter was used to measure the color parameters. Results were expressed as the mean of three measurements. The overall color difference $\left(\Delta \mathrm{E}^{*}\right)$ can be calculated using Eqn.

$\Delta E *=\sqrt{ }(L 0 *-L 1 *) 2+(a 0 *-a 1 *) 2+(b 0 *$ $-b 1 *) 2$

\section{Sensory evaluation}

The sensory evaluation of rice milk is done for two different samples. In one sample $10 \mathrm{gms}$ of sugar was added and in another sample mixture of chilli and salt was added. These samples were evaluated by 9 point Hedonic Scale reading.

In which the scale starts from 1 to 9 which represents dislike extremely to like extremely. In our sensory evaluation there are 5 members. The sample was given to those 5 members and the values are obtained.

\section{Results and Discussion}

Broken rice samples with 1:1, 1:2, 1:3, parts of water was soaked for $1 \mathrm{hr}, 2 \mathrm{hr}, 3 \mathrm{hr}$ at $80^{\circ} \mathrm{C}$ for 15 minutes, and cooked rice brokens mixture was blended with 1:1, 1:2 \& 1:3 parts of water. 


\section{pH values of rice milk}

$\mathrm{pH}$ values obtained for different cooking and different blending ratios with respect to soaking period by using digital $\mathrm{pH}$ meter are taken for ANOVA Test. The ANOVA Table for $\mathrm{pH}$ values were presented in Table 4.1.1.

\section{Effect on pH}

The $\mathrm{pH}$ values of rice milk during process conditions at different cooking ratios as 1:1, $1: 2,1: 3$ were presented in figure $3(a, b, c)$ respectively. The $\mathrm{pH}$ of broken rice beverage at all experimental conditions was found to be in the range of 5.70-6.10. From the ANOVA data it was noticed that cooking conditions and blending conditions have significant $\operatorname{effect}(\mathrm{p}<0.0001)$ on the $\mathrm{pH}$ value of broken rice beverage. At 1:1 cooking condition the $\mathrm{pH}$ values increased as the blending ratio increased from figure 3(a). At 1:2 cooking condition the $\mathrm{pH}$ values increased as the blending ratio increased from figure $3(\mathrm{~b})$. At $1: 3$ cooking condition the $\mathrm{pH}$ values increased as the blending ratio increased from figure 3(c). This may be due to increase in dilution of rice milk samples.

\section{TSS values of rice milk}

TSS values obtained for different cooking and different blending ratios with respect to soaking period by using digital refractrometer are taken for ANOVA Test. The ANOVA Table for TSS values were presented in Table 4.2.1.

\section{Effect on TSS}

The TSS values of rice milk during process conditions at different cooking ratios as 1:1, $1: 2,1: 3$ were presented in figure $4(a, b, c)$ respectively. The TSS of broken rice beverage at all experimental conditions were found to be in the range of 2.0 to 16.2. from the
ANOVA data it was noticed that cooking conditions and blending conditions have significant effect $(\mathrm{p}<0.0001)$ on the TSS value of broken rice beverage.

At 1:1 cooking condition the TSS values decreases as the blending ratio increases from figure 4(a). At 1:2 cooking condition the TSS values decreases as the blending ratio increases from figure 4(b). At 1:3 cooking condition the TSS values decreases as the blending ratio increases from figure 4(c). This may be due to increase in dilution of rice beverage samples.

\section{Titrable acidity (\%) values of rice milk}

Titrable aciditiy values obtained for different cooking and different blending ratios with respect to soaking period were taken for ANOVA Test. The ANOVA Table for titrable aciditiy values were presented in Table 4.3.1.

\section{Effect on titrable acidity}

The Titrable aciditiy values of rice milk during process conditions at different cooking ratios as 1:1, 1:2, 1:3 were presented in figure $5(\mathrm{a}, \mathrm{b}, \mathrm{c})$ respectively. The Titrable aciditiy of rice milk at all experimental conditions were found to be in the range of 0.02 to 0.08 . From the ANOVA data it was noticed that cooking conditions and blending conditions have no significant effect $(p>0.0001)$ on the titrable aciditiy value of broken rice beverage but soaking period has significant effect $(\mathrm{p}<0.0001)$.

At 1:1 cooking condition the titrable aciditiy values increased as the soaking period increased from figure 5(a). At 1:2 cooking condition the titrable aciditiy values increased as the soaking period increased from figure 5(b). At 1:3 cooking condition the titrable aciditiy values increased as the soaking period increased from figure 5(c). 
Table.1 ANOVA test for $\mathrm{pH}$ values of broken rice beverage

\begin{tabular}{|c|c|c|c|c|c|}
\hline Source & Sum of Squares & $\mathbf{d f}$ & Mean Square & F Value & p-value Prob $>$ F \\
\hline Model & 0.559954 & 6 & 0.093326 & 16.6679 & $<0.0001$ \\
\hline A-TIME & 0.1176 & 1 & 0.1176 & 21.00329 & 0.215 \\
\hline B-WC & 0.261807 & 1 & 0.261807 & 46.75864 & $<0.0001$ \\
\hline C-WB & 0.165557 & 1 & 0.165557 & 29.56845 & $<0.0001$ \\
\hline AB & 0.007511 & 1 & 0.007511 & 1.34148 & 0.2505 \\
\hline AC & 0.005878 & 1 & 0.005878 & 1.049767 & 0.3089 \\
\hline BC & 0.0016 & 1 & 0.0016 & 0.285759 & 0.5946 \\
\hline Residual & 0.414335 & 74 & 0.005599 & & \\
\hline $\begin{array}{c}\text { Lack of } \\
\text { Fit }\end{array}$ & 0.390002 & 20 & 0.0195 & 43.27418 & $<0.0001$ \\
\hline $\begin{array}{c}\text { Pure } \\
\text { Error }\end{array}$ & 0.024333 & 54 & 0.000451 & & \\
\hline Cor Total & 0.974289 & 80 & & & \\
\hline
\end{tabular}

Table.2 ANOVA Test for TSS values of milk prepared from broken rice

\begin{tabular}{|c|c|c|c|c|c|}
\hline Source & Sum of Squares & df & Mean Square & F Value & p-value Prob $>$ F \\
\hline Model & 880.4567 & 6 & 146.7428 & 53.30942 & $<0.0001$ \\
\hline A-TIME & 7.245341 & 1 & 7.245341 & 2.632122 & 0.1090 \\
\hline B-WC & 238.266 & 1 & 238.266 & 86.55842 & $<0.0001$ \\
\hline C-WB & 593.8823 & 1 & 593.8823 & 215.7484 & $<0.0001$ \\
\hline AB & 1.388469 & 1 & 1.388469 & 0.50441 & 0.4798 \\
\hline AC & 1.831511 & 1 & 1.831511 & 0.66536 & 0.4173 \\
\hline BC & 37.843 & 1 & 37.843 & 13.74779 & 0.0004 \\
\hline Residual & 203.6969 & 74 & 2.752661 & & \\
\hline Lack of & 87.61054 & 20 & 4.380527 & 2.037693 & 0.0199 \\
\hline Fit & 116.0864 & 54 & 2.149748 & & \\
\hline $\begin{array}{c}\text { Pure } \\
\text { Error }\end{array}$ & 1084.154 & 80 & & & \\
\hline Cor Total & & & & & \\
\hline
\end{tabular}


Table.3 ANOVA Test for titrable acidity values of broken rice beverage

\begin{tabular}{|c|c|c|c|c|c|}
\hline Source & Sum of Squares & df & Mean Square & F Value & p-value Prob > F \\
\hline Model & 0.015904 & 6 & 0.002651 & 0.975054 & $<0.0001$ \\
\hline A-TIME & 0.007257 & 1 & 0.007257 & 2.669418 & $<0.0001$ \\
\hline B-WC & 0.001195 & 1 & 0.001195 & 0.439476 & 0.5094 \\
\hline C-WB & 0.006801 & 1 & 0.006801 & 2.501573 & 0.1180 \\
\hline AB & $1.36 \mathrm{E}-06$ & 1 & $1.36 \mathrm{E}-06$ & 0.000501 & 0.9822 \\
\hline AC & $4.44 \mathrm{E}-07$ & 1 & $4.44 \mathrm{E}-07$ & 0.000163 & 0.9898 \\
\hline BC & 0.00065 & 1 & 0.00065 & 0.239189 & 0.6262 \\
\hline Residual & 0.201173 & 74 & 0.002719 & & \\
\hline Lack of Fit & 0.05684 & 20 & 0.002842 & 1.063302 & 0.4120 \\
\hline Pure Error & 0.144333 & 54 & 0.002673 & & \\
\hline Cor Total & 0.217078 & 80 & & & \\
\hline
\end{tabular}

Table.4 Color values of broken rice beverage

\begin{tabular}{|c|c|c|c|c|c|c|c|}
\hline Samples & $\mathrm{L}^{*}$ & $\mathbf{a} *$ & $\mathbf{b}^{*}$ & $\Delta \mathrm{L}$ & $\Delta \mathbf{a}$ & $\mathbf{\Delta b}$ & $\mathbf{\Delta E}$ \\
\hline $1: 1: 1$ & 83.26 & -0.53 & 11 & 3.19 & -1.37 & -4.72 & 5.851 \\
\hline $1: 1: 2$ & 83.11 & -1.60 & 9.47 & 3.04 & -0.3 & -3.19 & 4.416 \\
\hline $1: 1: 3$ & 81.82 & -1.83 & 6.98 & 1.79 & -0.07 & -0.7 & 1.886 \\
\hline $1: 2: 1$ & 84.44 & -0.66 & 9.96 & 4.37 & -1.24 & -3.68 & 5.846 \\
\hline $1: 2: 2$ & 82.02 & -1.49 & 7.84 & 1.95 & -0.41 & -1.56 & 2.530 \\
\hline $1: 2: 3$ & 79.08 & -2.07 & 4.81 & -0.99 & 0.17 & 1.47 & 1.780 \\
\hline $1: 3: 1$ & 82.47 & -1.09 & 8.84 & 2.4 & -0.81 & -2.56 & 3.60 \\
\hline $1: 3: 3$ & 75.32 & -2.24 & 2.88 & -4.75 & 0.34 & 3.4 & 5.851 \\
\hline
\end{tabular}

Table.5 Constraints for optimisation of rice milk process parameters

\begin{tabular}{|c|c|c|c|c|}
\hline Variable & Condition & Lower Limit & Upper Limit & Importance \\
\hline TIME & Maximize & 60 & 180 & 4 \\
\hline WC & is in range & 100 & 300 & 3 \\
\hline WB & is in range & 101 & 301 & 3 \\
\hline
\end{tabular}

\begin{tabular}{|c|c|c|c|c|}
\hline Responses & Condition & Lower Limit & Upper Limit & Importance \\
\hline $\mathbf{p H}$ & is in range & 5.75 & 6.15 & 3 \\
\hline TSS & maximize & 1.6 & 16.2 & 3 \\
\hline T.A & is in range & 0.018 & 0.39 & 3 \\
\hline
\end{tabular}


Table.6 Predicted optimum values for rice milk process parameters

\begin{tabular}{|c|c|c|c|c|c|c|c|}
\hline S. No & Time & Wc & Wb & $\mathbf{p H}$ & TSS & T.A & Desirability \\
\hline $\mathbf{1}$ & 180 & 100 & 101 & 5.759631 & 11.69902 & 0.079389 & 0.85388 \\
\hline $\mathbf{2}$ & 179.39 & 100 & 101 & 5.760127 & 11.70706 & 0.079273 & 0.851668 \\
\hline $\mathbf{3}$ & 180 & 102.7 & 101 & 5.762083 & 11.62002 & 0.079152 & 0.850995 \\
\hline
\end{tabular}

* selected for further studies

Table.7 Hedonic rating scale

\begin{tabular}{|c|c|c|}
\hline S. No & Feeling/Attribute & Rating \\
\hline $\mathbf{1}$ & Like extremely & 9 \\
\hline 2 & Like very much & 8 \\
\hline 3 & Like moderately & 7 \\
\hline 4 & Like slightly & 6 \\
\hline 5 & Neither like nor dislike & 5 \\
\hline 6 & Dislike slightly & 4 \\
\hline 7 & Dislike moderately & 3 \\
\hline 8 & Dislike very much & 2 \\
\hline 9 & Dislike extremely & 1 \\
\hline
\end{tabular}

Table.8 Score card

\begin{tabular}{|c|c|c|c|c|}
\hline Sample & Taste & Colour & texture & $\begin{array}{c}\text { Overall } \\
\text { acceptability }\end{array}$ \\
\hline S 1 & 7.8 & 8 & 7.8 & 7.86 \\
\hline S 2 & 7.2 & 8 & 7.4 & 7.53 \\
\hline
\end{tabular}

Flow chart for preparation of milk from rice brokens

\section{Broken Rice}

Soaking (1hr, 2hr, 3hr)

$\stackrel{\downarrow}{\text { Draining }}$

Cooking (1:1, $1: 2,1: 3)$ at $80^{\circ} \mathrm{C}$

Blending with water $(1: 1,1: 2,1: 3)$

Rice milk 
Fig.1 Measurement of $\mathrm{pH}$ using digital $\mathrm{pH}$ meter

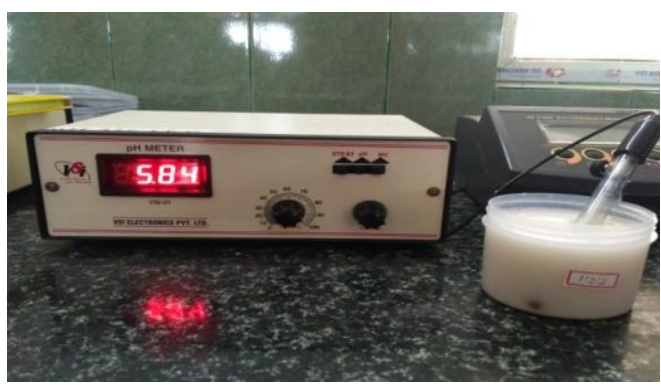

Fig.2 Measurement of color using Hunter lab colorimeter

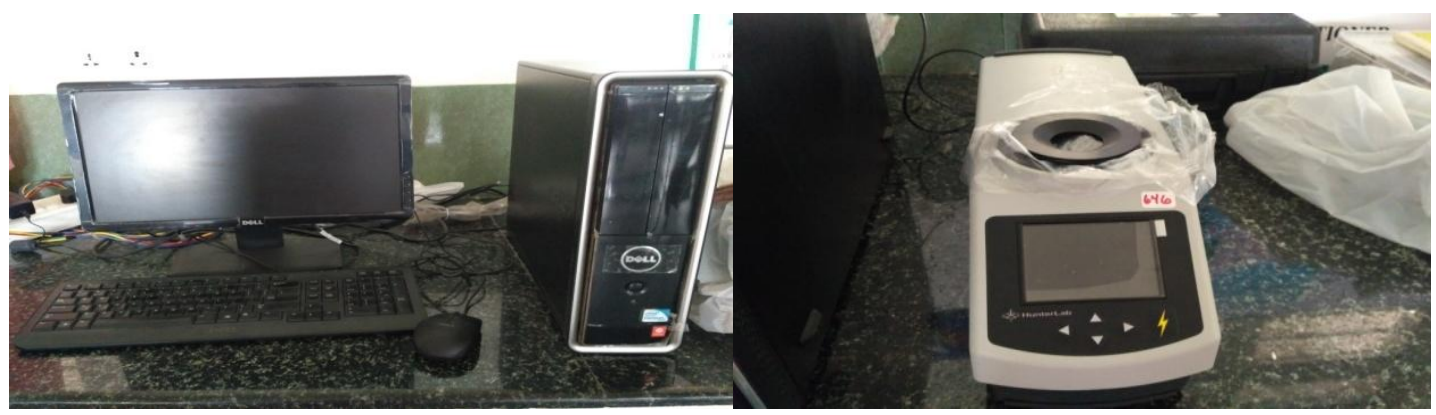

Fig.3 (a) Soaking period Vs pH at 1:1 cooking

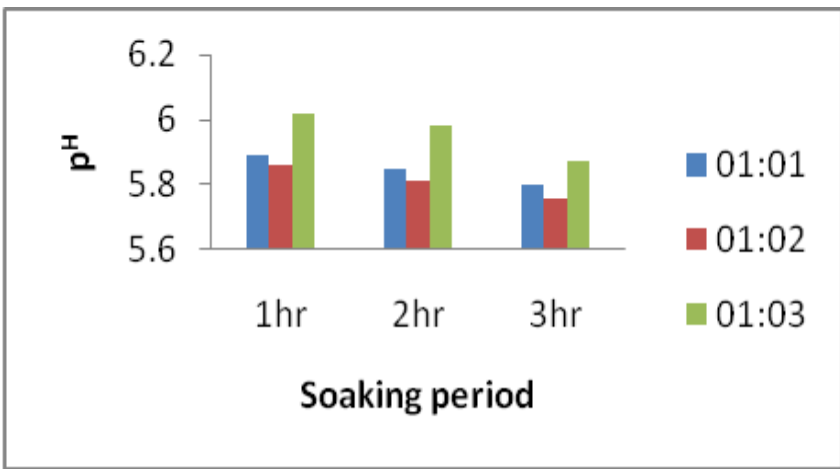

Fig.3 (b) Soaking period Vs pH at 1:2 cooking

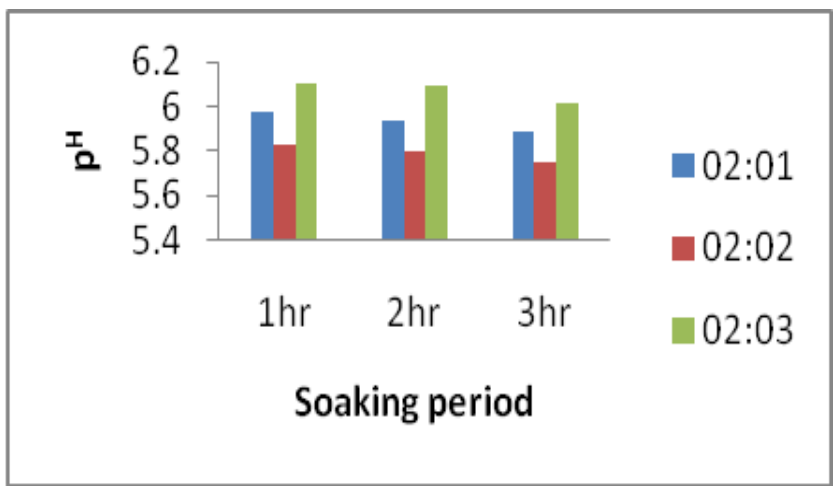


Fig.3 (c) Soaking period Vs pH at 1:3 cooking

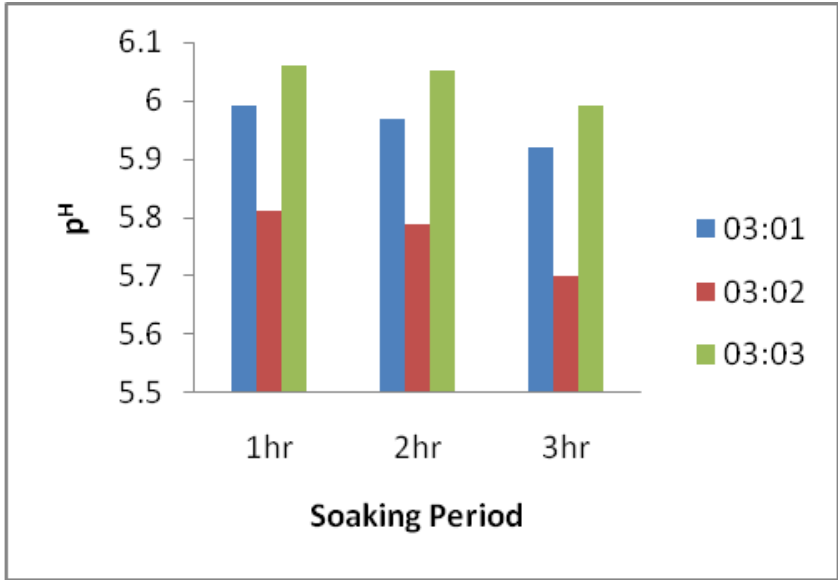

Fig.4 (a) Soaking period Vs TSS at 1:1 cooking

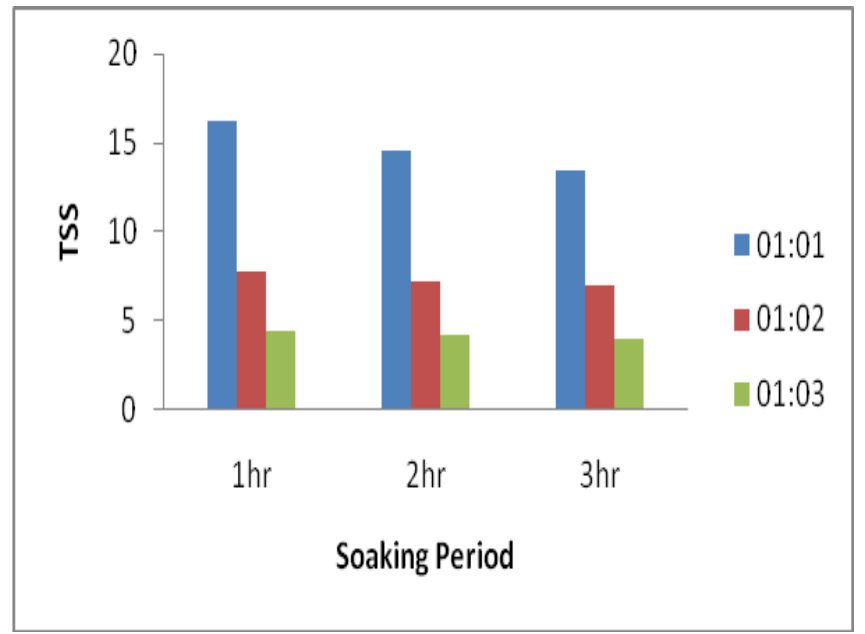

Fig.4 (b) Soaking period Vs TSS at 1:2 cooking

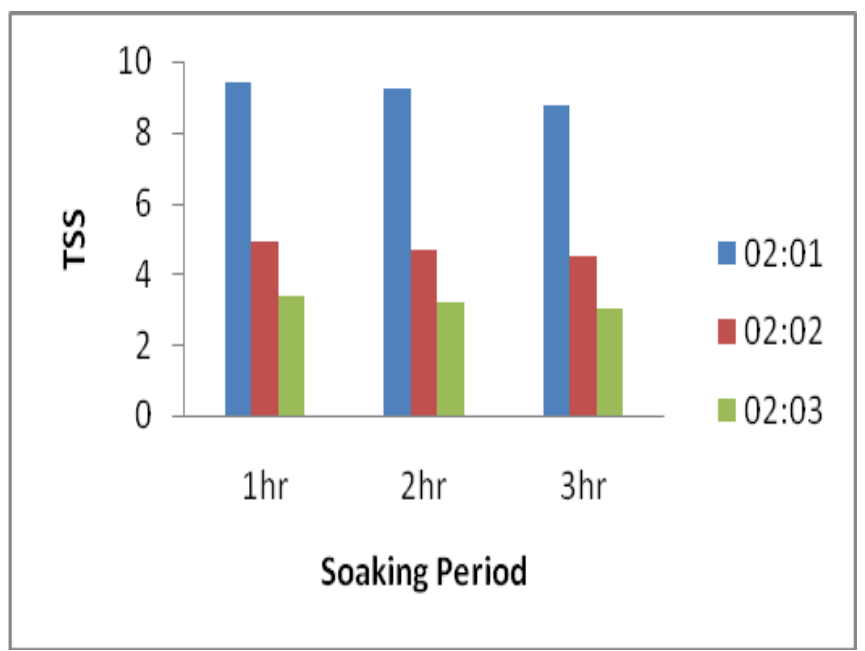


Fig.4 (c) Soaking period Vs TSS at 1:3 cooking

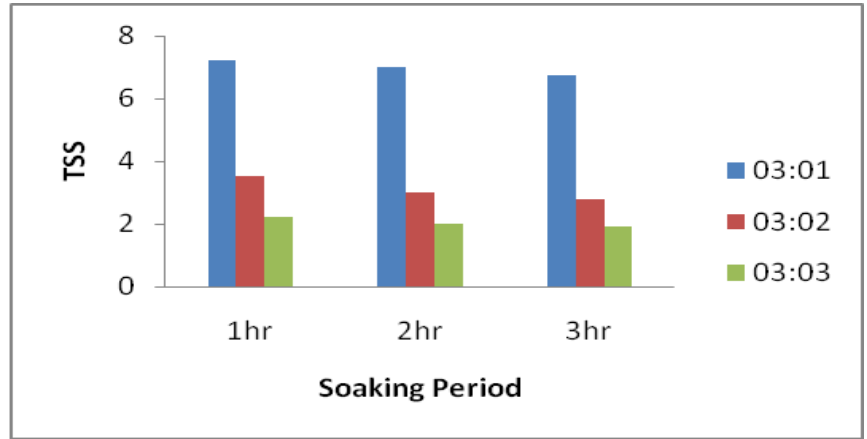

Fig.5 (a) Soaking period Vs TA at 1:1 cooking

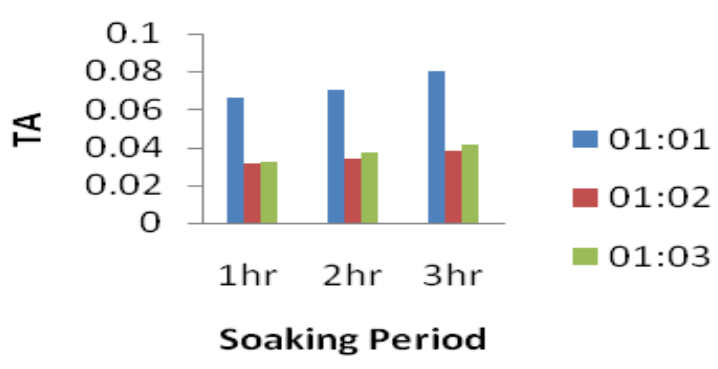

Fig.5 (b) Soaking period Vs TA at 1:2 cooking

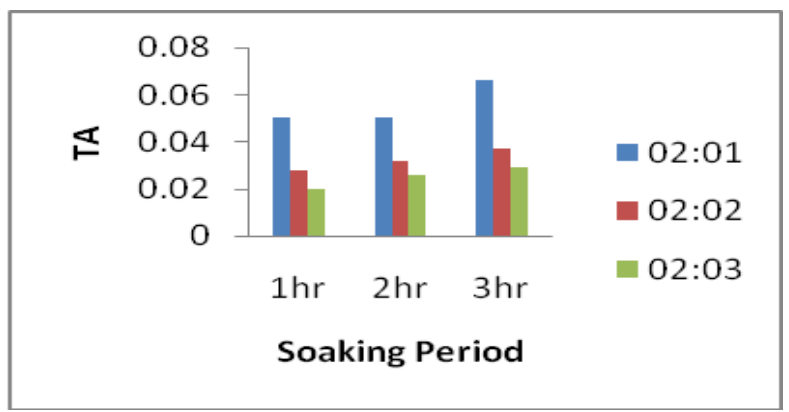

Fig.5 (c) Soaking period Vs TA at 1:3 cooking

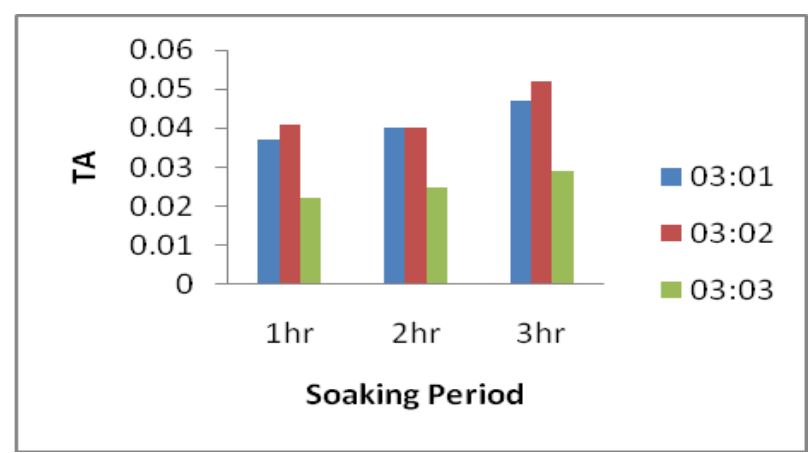




\section{Colour values}

1:3:2 ratio of rice milk sample was taken as reference as it looks clear liquid of white color. From the Hunter lab colorimeter, L*, $a^{*}, b^{*}$ values obtained were:

Here 1:1:1 indicates quantity of broken rice: cooking water: blending water.

From the table 1:1:1 sample has high color difference and 1:2:3 sample has least color difference that is nearly white

\section{Optimization of process parameters}

Optimization condition for rice milk process was determined with the help of commercial software (Design Expert Version 7.0.0) to obtain optimum sample with maximum TSS and in range $\mathrm{pH} \&$ Titrable acidity values.

\section{Rice milk process parameters}

The optimisation of rice milk was aimed maximum changes in Total soluble solids and in range values of $\mathrm{pH}$ and Titrable acidity. The detailed parameters with their importance are shown in table. And the obtained optimum conditions were presented in table 4.5.1.

\section{Sensory evaluation values}

We have taken two samples, in one of the sample of $100 \mathrm{ml}$ sugar of about $10 \mathrm{~g}$ was added and in other sample of $100 \mathrm{ml}$ salt with chilli mix of about $7.5 \mathrm{~g}$ was added.

These two samples were evaluated for sensory evaluation by 5 panelists. Panelists have given rating for these two samples based on Hedonic scale rating. This scale consists of $1-9$ rating from dislike extremely.

Panelists evaluated how was the texture, color and overall acceptability. Average values obtained for sensory evaluation are as follows.

From the values, sample with sweetness has high overall acceptability, salt cum chilli mix sample has less overall acceptability values.

Broken rice was taken as raw material as these are low in cost.

The present study was under taken to increase the income to the farmers by converting broken rice into value added products. From the above work the conclusions are:

Broken rice samples of $1 \mathrm{~kg}$ were soaked for $1 \mathrm{hr}, 2 \mathrm{hr}$ and $3 \mathrm{hr}$ and cooked with 1:1, 1:2, 1:3 parts of water and $\alpha$-amylase at $80{ }^{\circ} \mathrm{C}$ for 15 min. The resultant mixture of each sample was blended with 1:1, 1:2, 1:3 parts of water and drained. Xanthangum was added to the prepared rice beverage to prevent settling of particles in it.

The blending conditions have significant effect $(\mathrm{p}<0.0001)$ on $\mathrm{pH}$ values of broken rice beverage. The $\mathrm{pH}$ values increased as the blending ratio increased.

The blending conditions have significant effect $(p<0.0001)$ on TSS values of broken rice beverage. The TSS values decreased as the blending ratio increased.

Soaking period has significant effect $(p<0.0001)$ on titrable acidity values of broken rice beverage. Titrable acidity values increased as the soaking period increased.

From the Design Expert software the optimised broken rice beverage sample was at $3 \mathrm{hr}$ soaking, 1:1 cooking and 1:1 blending.

Overall acceptability of sample S1 was higher when compared to S2 and the sample S1is the best. 


\section{References}

Aadil Abbas, Shahzad Murtaza, Faiza Aslam, Ayesha Khawar, Shakeela Rafique and Sumera Naheed. 2011. Effect of Processing on Nutritional Value of Rice (Oryza sativa). World Journal of Medical Sciences 6 (2): 68-73. ISSN 1817-3055

Aadil, A., Shahzad, M., Faiza, A., Ajehsa, k., Shakee, A. R. and Sumera N. 2011. Effect of Processing on Nutritional Value of Rice. World Journal of Medical Sciences. Vol. 6(2.): 69.

Ackerman, A.H., Creed, P.A., Parks, A.N., Fricke, M.W., Schwegel, C.A., Creed, J.T., Heitkemper, D.T., Vela, N.P. Comparison of a chemical and enzymatic extraction of arsenic from rice and an assessment of the arsenic absorption from contaminated water by cooked rice. Environ. Sci. Technol., 2005, 39, 5241-5246.

Alary, V. 1999. Rice cultivation in Telangana: Comparative study in Irrigated and Non-Irrigated zones, Economic \& Political weekly, Vol. 34 (23), pp 14021404.

Amal A. Hassan, Mona M.A. Aly and Soher T. El-Hadidie. 2012. Production of Cereal-Based Probiotic Beverages. World Applied Sciences Journal 19 (10): 1367-1380

Asghar, S., Anjum, F.M., Amir, M.R. and Khan, M. A. 2012. Cooking and eating characteristics of Rice (Oryza sativa L.)-A review. Pakistan Journal of Food Sciences 22: 128-1

Cao Thi Luyen, Ho Thanh Binh. 2015. Hydrolysis of starch using alphaamylase and glucoamylase during the processing of rice milk from some rice varieties in an giang province. Journal of Science, Vol. 3 (3), 138 - 148

Chakkaravarthi, A. Lakshmi, S. Subramanian, R and Hegde 2008. Kinetics of cooking unsoaked and presoaked rice. J. of Food Eng. 84, 181-186.

El-Hissewy, A.A., F.R. Laila and A.D. Hanaa, 2002. Atatürk University, pp: 238. Effect of degree of milling on the chemical composition and nutritional value of the milled rice. 80(1): 341-353.

Folorunso A. A, Omoniyi S. A, Adeleye A. E.1, Okeke C. E. 2016. Proximate Composition and Sensory Qualities of Milk Produced from Five Varieties of Rice (Oryza sativa). American Journal of Food Science and Nutrition Research; 3(5): 109-112

Georg Steiger, Nadina M"uller-Fischer, Hector Cori, and B'eatrice Conde-Petit. 2014. Fortification of rice: technologies and nutrients. Ann. N.Y. Acad. Sci. ISSN 0077-8923

Gunasekara, K.G., and D.A.N. Dharmasena. 2011. Effect of Grain Shape and Presoaking on Cooking Time and Cooking Energy. Tropical Agricultural Research Vol. 22 (2): 194 - 203

Kale, S. J., S. K. Jha, G. K. Jha, J. P. Sinha, S. B. Lal. 2015. Soaking induced changes in Chemical Composition, Glycemic Index and Starch Characteristics of Basmati Rice. Rice Science, 22(5): 227-236.

Kitamura Yutaka, Koyama Masaru. 2014. Development of a new rice beverage by improving the physical stability of rice slurry. Journal of Food Engineering 131(89-95)

Miah, M.A.K., Haque, A., Douglass, M.P. \& Clarke, B. 2002. Parboiling of rice. Part II: Effect of hot soaking time on the degree of starch gelatinization. International Journal of Food Science and Technology 37: 539-545.

Mueller-Fischer, N. 2012. "Nutrient focused rice processing." In Agricultural Sustainability: Process and Prospects in Crop Research. G.S. Bhullar \& N.K. Bhullar, Eds.: 197-218. India: Elsevier. 
Porasuphatana, S. et al., 2008. Production and shelf stability of multiple fortified quick cooking rice as a complementary food. J. Food Sci. 73: S359-S366.

Rousset, S., Pons, B. and Pilandon, C. Sensory texture. Profile, grain physicochemical characteristics and in117. Strumental measurements of cooked rice. J Texture Stud 26 (1995) 119-135.

Umadevi, M., R. Pushpa1, K.P. Sampathkumar, Debjit Bhowmik. 2012.
Rice-Traditional Medicinal Plant in India. Journal of Pharmacognosy and Phytochemistry. Vol. 1(1).

Vaughan, D. A., Lu, B. R, and Tomooka, N. 2008. The evolving story of rice evolution. Plant Sci. 174(4), 394-408.

Villareal, R.M., Resurreccion, A.P., Suzuki, L.B. and Riso 26 1977. 253265.Juliano, B.O. Changes in physicochemical properties of Starch/Starke 28 (1976) 88-94.

\section{How to cite this article:}

Padma, M., P.V.K. Jagannadarao, L. Edukondalu, G. Ravibabu and Aparna, K. 2018. PhysicoChemical Analysis of Milk Prepared from Broken Rice. Int.J.Curr.Microbiol.App.Sci. 7(02): 426-428. doi: https://doi.org/10.20546/ijcmas.2018.702.054 